\title{
Consumer bankruptcy in Poland
}

\author{
Rafal Adamus ${ }^{\star}$ \\ Faculty of Law and Administration, Opole University, Poland \\ email: radamus@uni.opole.pl
}

ADAMUS, Rafał. Consumer bankruptcy in Poland. International and Comparative Law Review, 2011, Vol. 11., No. 2, pp. 93-107. DOI: 10.1515/iclr-2016-0106.

\begin{abstract}
The article analysis the legal aspects of the problem of consumer bankruptcy within the Polish legal system. It covers the substantive and also procedural aspects of this legal instrument. Author describes the requirements and conditions for the consumer bankruptcy, scope and effects of this form of bankruptcy. Moreover he deals with the procedural aspects of the declaration of the personal consumer bankruptcy and discusses the practice of use of this institution in Poland.
\end{abstract}

Keywords: Bankruptcy, consumer, requirements, conditions, scope, procedures

\section{Introduction}

The Act of 5 December 2008 on amending the Bankruptcy and Reorganization Law and the Act on Court Costs in Civil Proceedings introduced to the Bankruptcy and Reorganization Law of 28 February 2003 the rules concerning special bankruptcy proceedings against natural persons not conducting commercial activity ("the consumer bankruptcy"). ${ }^{1}$ The former Ordinance of the

* Prof. UO dr hab. Rafał Adamus, head of Department of Commercial Relationships of Opole University - Faculty of Law and Administration, legal advisor (radca prawny) and arbiter.

1 F. Zedler, in: A. Jakubecki, F. Zedler, Prawo upadłościowe i naprawcze. Komentarz, Warszawa 2010, p. 921, P. Tereszkiewicz, Postępowanie upadłościowe i oddłużeniowe dla konsumentów $w$ Stanach Zjednoczonych i niektórych krajach europejskich, Transformacje Prawa Prywatnego 2000, no 1-3, part. I i no 3, part. II, W. Szpringer, Kredyt konsumencki i upadłość konsumencka na rynku usług finansowych UE, Warszawa 2005, s. 74-76, W. Szpringer, Regulacja upadłości konsumenckiej (inspiracje z rozwiązań światowych), Monitor Prawniczy 2008, no 23, p. 26, S. Gurgul, Postępowanie upadłościowe wobec osób fizycznych nieprowadzących działalności gospodarczej - cz. I, Monitor Prawniczy 2009, no 10, p. 527, S. Gurgul, Prawo upadłościowe i naprawcze. Komentarz, Warszawa 2010, p. 1251, C. Zalewski, Nowelizacja prawa upadłościowego i naprawczego, Przegląd Prawa Handlowego 2009, no 5, p. 4, R. Lewandowski, G. Tarkotta, P. Wołowski, Projekt ustawy o przeciwdziałaniu niewypłacalności oraz upadłości osoby fizycznej na tle niemieckiej regulacji upadłości konsumenckiej - uwagi de lege lata i de lege ferenda, Rejent 2008, no 1, p. 
President of the Republic of 24 October 1934 - Bankruptcy Law, the first Polish modern source of the bankruptcy law, and the Bankruptcy and Reorganization Law of 28 February 2003 until the above mentioned amendment applied only to the entrepreneurs. ${ }^{2}$ In other words bankruptcy capacity had been given mainly to the persons or entities conducting commercial activity. De lege lata the consumer bankruptcy should be consider as separate, special bankruptcy proceedings among other specific proceedings i.e. bankruptcy proceedings against banks, mortgage banks, credit institutions, bond issuers, developers, etc. Bankruptcy proceedings against natural persons not conducting commercial activity is regulated in art. $491^{11}-491^{12}$ b.r.l..$^{3}$ The legal norms of the Polish bankruptcy law are divided into norms of substantive, political (structural) and procedural law. ${ }^{4}$ The European law does not provide any special regulation in the matter of the consumer bankruptcy. In the time of the global financial crisis the consumer bankruptcy in Poland in the present legal shape is not a popular institution in practice. The aim of this paper is to give a short overview of the Polish bankruptcy law for consumers and the reasons of unpopularity of the present bankruptcy law.

\section{Subjective scope of applicability of the consumer bankruptcy ("consumer bankruptcy ability")}

The consumer bankruptcy, as special bankruptcy proceedings, shall apply only to those natural persons to whom the provisions of the general bankruptcy proceedings do not apply (art. $491^{1}$ b.r.l.). ${ }^{5}$ The Act of 23 April 1964 - Civil Code in art. $22^{1}$ defines the phrase "consumer". The scope of the word "consumer"

98, A. Bunk, V. Lichter, M. Pietrzak, Upadłość konsumencka w Niemczech, Fenix 2011, no 4, p. 29, K. Babiarz - Mikulska, Postępowanie upadłościowe wobec osób nieprowadzących działalności gospodarczej, Przegląd Prawa Handlowego 2011, no 2, p. 55, W. Głodowski, A. Hrycaj, Zakres podmiotowy i podstawy ogłoszenia „upadłości konsumenckiej”, Państwo i Prawo 2010, no 2, p. 70, O. Zachmielewska, Upadłość konsumencka w świetle domniemania racjonalności ustawodawcy, Państwo i Prawo, 2010 no 11, p. 96, R. Adamus, A.J. Witosz, A. Witosz, Upadłość konsumencka. Komentarz praktyczny, Warszawa 2009, R. Adamus, A.J. Witosz, A. Witosz, in: R. Adamus, H. Buk, D. Chrapoński, P. Dragon, L. Guza, W. Klyta, S. Ociessa, A. Pokora, A.J.Witosz, A. Witosz, L. Zieliński, Prawo upadłościowe i naprawcze. Komentarz, Warszawa 2010, p. 808, R. Adamus, Wierzytelności banku w upadłości konsumenckiej, Jurysta 2009, no 3-4, p. 41, R. Adamus, Bank wobec upadłości konsumenckiej swojego dłużnika, Monitor Prawa Bankowego 2011, no 2, p. 53.

2 The Act sets forth some minor exemptions of the general rule that bankruptcy capacity is given to an entrepreneur.

3 Consumer bankruptcy shall be conducted according to the provisions on the general bankruptcy proceedings by liquidation of the bankrupt's assets applied accordingly, however some of the provisions shall not apply (art. $491^{2}$ sec. 1 b.r.l.).

4 R. Adamus, Miejsce Prawa upadłościowego i naprawczego w systemie prawa, Przegląd Ustawodawstwa Gospodarczego, 2011, no 1, p. 3.

5 F. Zedler, in: Prawo..., p. 921, S. Gurgul, in: Prawo..., p. 1252, R. Adamus, A.J. Witosz, A. Witosz, in: Prawo..., p. 808. 
under the regulation of the Civil Code and the scope of the phrase "natural person not conducting commercial activity" are not the same. ${ }^{6}$

It should be stated that general bankruptcy proceedings applies to the natural persons who are entrepreneurs as defined in the Act of 23 April 1964 - Civil Code - art. $43^{1}$ (art. 5 sec. 1 b.r.l.). ${ }^{7}$ Entrepreneur under the Civil Code is a natural person, legal person, or an organizational entity not possessing legal personality, yet whose legal capacity is recognized by a separate statute, engaging in a commercial or professional activity exclusively in its own name. It is obvious that entrepreneurs cannot start consumer bankruptcy. ${ }^{8}$ Secondly general bankruptcy proceedings applies to the natural persons who are partners in commercial partnerships, liable without limitation with their whole property for the obligations of the partnership or partners in a professional partnership (art. $5 \mathrm{sec} .2$ point 2,3 b.r.l.). ${ }^{9}$ The above mentioned partners may be declared bankrupt under general rules of the bankruptcy proceedings. On the contrary, the consumer bankruptcy is available for shareholders of a joint stock company because they are not responsible for the debts of the company. Thirdly general bankruptcy proceedings apply to a natural persons who was an entrepreneur and not more than one year has passed between the date the entrepreneur had been deleted from the appropriate register and the date of the submission the declaration of bankruptcy (art. 8 br.l.). ${ }^{10}$ In fact it depends on passage of time if ex-entrepreneur may start general bankruptcy or consumer bankruptcy. Fourthly general bankruptcy proceedings applies to a natural person who conducted commercial activity and failed to perform his legal obligation to notify the appropriate register (art. 9 b.r.l.). ${ }^{11}$ In fact, as a general rule, the consumer bankruptcy may be declared to the natural persons who are consumers. The consumer bankruptcy also applies to a natural person operating an agricultural farm as the general bankruptcy proceeding cannot be declared in respect of such a person (art. 6 point 5 b.r.l.).

The legal nature of debts of the natural persons ("commercial" or "private") has no importance on the commented matter. In theory the bankruptcy court may declare bankruptcy of the natural person - the entrepreneur with the "private" debts and the bankruptcy of the natural person - consumer with "commercial" debts. The age of the natural person has no importance in the discussed matter. Bankruptcy courts are entitled to declare bankrupt a person aged under

6 W. Głodowski, A. Hrycaj, Zakres podmiotowy..., p. 71.

7 General bankruptcy proceedings also applies to the entrepreneurs who are a legal person or an organizational entity not possessing legal personality, whose legal capacity is recognized by a separate status.

8 E. Gniewek, in: Kodeks cywilny. Komentarz, ed. E. Gniewek, Warszawa 2011, 4th. ed., p. 98, M. Pazdan, in: System prawa prywatnego. Prawo cywilne - część ogólna, Ed. M. Safjan, Part. I, Warszawa 2007, p. 1001.

9 F. Zedler, in: Prawo..., p. 26, S. Gurgul, in: Prawo..., p. 32, R. Adamus, in: Prawo..., p. 38.

10 F. Zedler, in: Prawo..., p. 33, S. Gurgul, in: Prawo..., p. 52, R. Adamus, in: Prawo..., p. 55.

11 F. Zedler, In: Prawo..., p. 33, S. Gurgul, in: Prawo..., p. 53, R. Adamus, in: Prawo..., p. 57. 
18 years old. An incapacitated person may be declared bankrupt as well. Such a person should act in the proceedings by a statutory agent. Citizenship or nationality does not influence the legal capacity in the consumer bankruptcy. The consumer bankruptcy may not converse into the entrepreneur bankruptcy as well the entrepreneur bankruptcy may not converse into the consumer bankruptcy. It also should be clearly stated that the reorganization proceedings (art. $492-521$ b.r.l.) is available exclusively for entrepreneurs ${ }^{12}$ with the exemption of natural persons not conducting commercial activity.

\section{Grounds for declaration of consumer bankruptcy}

Under Polish bankruptcy law bankruptcy shall be declared to a debtor who has become insolvent (art. 10 b.r.l.). A debtor who is a natural person shall be deemed insolvent when he fails to perform his due financial obligations (art. 10 sec. 1 b.r.l.). This ground for declaration of bankruptcy is called "the lack of disposable assets". The bankruptcy cannot be declared if there is only one creditor of the debtor because the bankruptcy proceedings are collective pursuits of claims by creditors against the insolvent debtor. Insolvency is the positive ground for declaration of the consumer bankruptcy. ${ }^{13}$ The separate ground for declaration of bankruptcy called "the excessive debts" ${ }^{14}$ does not apply to natural persons.

The amended Act also sets forth the special grounds for declaration of the consumer bankruptcy. ${ }^{15}$ The bankruptcy court shall dismiss the petition to declare bankruptcy if the insolvency of the debtor was not caused by extraordinary circumstances not attributable to the debtor (art. $491^{3} \mathrm{sec} .1 \mathrm{br} . \mathrm{l}$.). What are the "extraordinary circumstances not attributable to the debtor"? The amended Act gives two legal examples. First, the debtor contracted obligations while being insolvent. Second, debtor's employment relationship was terminated due to the reasons attributable to the employee or upon the mutual consent of both parties. ${ }^{16}$ In fact the consumer bankruptcy is not available for any natural person not

12 Reorganization proceedings shall apply to entrepreneurs who are threatened with insolvency. An entrepreneur shall be deemed to be threatened with insolvency even he duly performs its obligations when - based on rational estimate of economic condition - it is apparent than the entrepreneur will become insolvent within a short period of time (art. 492 sec. 1, 2 b.r.l.). Additionally the court upon motion of the debtor may allow the debtor to institute reorganization proceedings if the court dismisses the petition to declare bankruptcy when the delay in performing the obligations does not exceed three months and the amount of unperformed obligations does not exceed 10 per cent of the balance sheet value of the debtor's enterprise (art. $12 \mathrm{sec} .1,3$ b.r.l.).

13 F. Zedler, in: Prawo..., p. 34, S. Gurgul, in: Prawo..., p. 54, R. Adamus, in: Prawo..., p. 59.

14 Article $11 \mathrm{sec} .2$ b.r.l. sets forth that a debtor who is a legal person or an organizational entity not possessing legal personality, yet whose legal capacity is recognized by a separate statue ahall also be deemed insolvent when the sum of his obligations exceeds the value of his assets, even if the debtor duly performs the obligations as they fall due.

15 See among others: O. Zachmielewska, Upadłość konsumencka..., p. 97.

16 F. Zedler, in: Prawo..., p. 925, S. Gurgul, in: Prawo..., p. 1262, R. Adamus, A.J. Witosz, A. 
conducting commercial activity, but there are strong limitations. De lege ferenda consumer bankruptcy shall be available for any natural person not conducting commercial activity who is insolvent. Special grounds should be provided only for discharging of the unsatisfied obligations of the bankrupt in the bankruptcy proceedings. De lege lata the above mentioned grounds for declaration of consumer bankruptcy are similar to the basis for discharging obligation of the bankrupt - entrepreneur, who is a natural person, under art. 369 b.r.l. The institution of the repayment plan and discharging obligations in consumer bankruptcy is similar to discharging obligations of the bankrupt - entrepreneur. ${ }^{17}$

The list of the grounds for declaration of consumer bankruptcy is not finished yet. The bankruptcy court shall dismiss the petition to declare bankruptcy of the consumer if, within the period of 10 years prior to the filing of petition to declare bankruptcy, any of the following proceedings were conducted with regard to the debtor (negative grounds):

1. bankruptcy proceedings or other proceedings, in which all or a part of the debtor's obligations were discharged or in which an arrangement was made

2. bankruptcy proceedings in which not all of the creditors had been satisfied, and after the closure or discontinuance or the proceedings the debtor failed to perform his obligations

3. former consumer bankruptcy proceedings were discontinued for reasons other than upon a motion of all of the creditors

4. any legal act of the debtor was validly declared performed to the creditor's detriment.

A very long list of special grounds for declaration of the consumer bankruptcy seems to be one of the crucial reasons of unpopularity of the consumer bankruptcy in practice. The main principles of general bankruptcy proceedings is listed in art. 2 b.r.l.: the proceedings governed by the Bankruptcy and Reorganization Law should be conducted in a manner which provides for the maximum satisfaction of the creditors' claims and when rational - for the preservation of the debtor's enterprise. In case of the consumer bankruptcy the main principles should be modified. The consumer interest should be protected as well because a typical consumer is a weaker participant of the legal relationships. The law should compromise the two opposite interests: the interest of the creditors and the interest of the debtor - consumer.

\section{Entitlement to file the petition to declare consumer bankruptcy}

As a general rule the power to file the petition to declare bankruptcy has the debtor or any of his creditors (art. 20 br.l.). ${ }^{18}$ But the petition to declare consumer

Witosz, in: Prawo..., p. 829.

17 F. Zedler, in: Prawo..., p. 765, S. Gurgul, in: Prawo.., p. 1096, L. Guza, in: Prawo..., p. 649.

18 A. Jakubecki, in: Prawo..., p. 50, S. Gurgul, in: Prawo..., p. 75, S. Ociessa, in: Prawo..., p. 96. 
bankruptcy may be filed only by the debtor - consumer (art. $491^{2}$ sec. 1). Creditors (for example banks) are not entitled to file the petition for a declaration of bankruptcy of the debtor. Ratio legis of this provision is the consumer protection. The legal effects of declaring bankruptcy are very serious. In these circumstances the choice of the solution is given exclusively to the insolvent debtor. Execution proceedings could be more advantageous for a consumer than bankruptcy proceedings. The consumer, in contrast to the entrepreneur, has no legal duty to file the petition. Article 21 b.r.l., which states that the debtor shall, no later than within two weeks of the day on which the grounds for declaring bankruptcy occurred $^{19}$, file a petition to declare bankruptcy, does not apply to the consumer bankruptcy. This regulation should be evaluated as reasonable. The consumer has possibility to file in court the petition for a declaration of bankruptcy.

\section{Formal requirements of the petition}

The petition to declare consumer bankruptcy is one of the most complicated motions in the Polish civil proceedings. The list of formal requirements of the petition and of the additional documents which are strictly required is in art. 22 and 23 b.r.l..$^{20}$ The petition to declare bankruptcy shall contain, among other requirements, the description of circumstances justifying the petition as well as demonstration of their probability (art. $22 \mathrm{sec} .1$ point 3 b.r.l.). The court fee of the debtor's petition to declare consumer bankruptcy is 200 Polish zlotys. The court fee of the petition do declare "ordinary" bankruptcy is 1000 Polish zlotys. The separate provisions on exemption from court costs shall apply with respect to the debtor (see art. $491^{2} \mathrm{sec} .1$ and art. $31 \mathrm{sec}$. 1 b.r.l.). Consumers may apply to the court for an agent for litigation, as well. The conclusion of the practical researches in this matter is the following: formal requirements are two difficult for an average consumer.

\section{The problem of insufficiency of the assets of the insolvent debtor}

Consumer bankruptcy keeps a general rule of art. 13 b.r.l. Article 13 section 1 b.r.l. stipulates that the bankruptcy court shall dismiss the petition to declare bankruptcy when the assets of the insolvent debtor are not sufficient to cover the costs of the proceedings. ${ }^{21}$ The costs of the consumer bankruptcy proceedings include court fees and expenses necessary to achieve the purpose of the proceedings. The expenses include the remuneration and expenses of the trustee, costs of service, announcements ${ }^{22}$ and notices, taxes and other public levies due

19 A. Jakubecki, in: Prawo..., p. 66, S. Gurgul, in: Prawo..., p. 86, S. Ociessa, in: Prawo..., p. 107.

20 A. Jakubecki, in: Prawo..., p. 61, S. Gurgul, in: Prawo..., p. 82, S. Ociessa, in: Prawo..., p. 102.

21 F. Zedler, in: Prawo..., p. 39, S. Gurgul, in: Prawo..., p. 75, R. Adamus, in: Prawo..., p. 77.

22 The announcement of the ruling declaring consumer bankruptcy shall be made by publication of the announcement In at least one $\mathrm{n}$ a $\mathrm{I}$ o $\mathrm{n}$ a $\mathrm{l}$ daily newspaper (art. $491^{2} \mathrm{sec}$. 2 b.r.l.). While the announcement of the ruling declaring entrepreneur's bankruptcy shall be made by publication of the announcement In a local daily newspaper (art. $53 \mathrm{sec} .1$ ). O. 
for the period following the declaration of bankruptcy, expenses connected to liquidation of the bankruptcy estate (art. 230 b.r.l.). The costs of the bankruptcy proceedings shall be paid out from the bankruptcy estate (art. $231 \mathrm{sec} .1$ b.r.l.). In practice bankruptcy courts very often dismiss petitions of consumers because, in many cases, the debtors are too poor to cover the estimated costs of the proceedings.

In fact there are two main goals of the bankruptcy proceedings: satisfaction of the creditors' claims based on liquidation of the bankruptcy estate and recovery of the debtor by discharging of the unsatisfied obligations of the bankrupt. Ratio legis of art. 13 is clearly connected with the satisfaction of the creditor's claims. It is useless to conduct liquidation if the assets are not enough to cover the costs of the proceedings. Nevertheless the crucial goal of the consumer bankruptcy is to give a "fresh start" to the consumer. In other words there are reasonable reasons to conduct bankruptcy proceedings despite of the lack of assets to cover the costs of the proceedings. De lege ferenda it should be found a solution which allows to conduct bankruptcy proceedings even if the consumer's estate is not sufficient to satisfy the costs of proceedings.

\section{Proceedings to secure the assets}

After the petition to declare consumer bankruptcy has been filed the bankruptcy court should ex officio secure debtor's assets. The court shall make the decision with regard to securing the debtor's debt immediately (art. 36 b.r.l.). Proceedings to secure the assets of the consumer are obligatory. The court may secure the debtor's assets through the appointment of an interim court supervi$\operatorname{sor}^{23}$ (art. $38 \mathrm{sec} .1$ b.r.l.). The court may apply other measures to secure the assets of the debtor, in particular may order mandatory administration ${ }^{24}$ of debtor's assets, if reasons exist to fear that the debtor might conceal his assets or otherwise act to the detriment of the creditors, or if the debtor does not obey the instructions of the interim court supervisor (art. $40 \mathrm{sec} .1$ b.r.l.). Upon declaring bankruptcy security in the form of appointing an interim court supervisor or ordering mandatory administration shall be revoked at the moment the administration of the bankrupt's assets is taken over by a trustee. Other security ordered by the bankruptcy court shall be revoked upon the date the bankruptcy is declared (art. 43 b.r.l.).

\section{Effects of declaring consumer bankruptcy}

Under the Bankruptcy and Reorganization Law there are two manners of conducting bankruptcy proceedings of the debtor: bankruptcy with the possibility to make an arrangement (art. 14 b.r.l.) and bankruptcy involving the liq-

Zachmielewska, Upadłość konsumencka..., p. 104.

23 In Polish: „tymczasowy nadzorca sądowy”.

24 In Polish: „zarządca przymusowy”. 
uidation of debtor's estate (art. 15 b.r.l.). In case of consumer bankruptcy the proceedings shall be conducted exclusively according to the provisions of bankruptcy involving the liquidation of debtor's estate (art. $491^{2}$ section 1 b.r.l.). Reorganization proceedings in the case of treat of insolvency are not available for a consumer. ${ }^{25}$ The consumer bankruptcy cannot convert into the "general bankruptcy proceedings" ${ }^{26}$ On the other hand the "general bankruptcy proceedings" cannot convert into the consumer bankruptcy. The changes of the status of the bankrupt, after decision declaring bankruptcy has been passed, have no influence on the type of the proceedings.

In approving the petition on a declaration of bankruptcy the court shall issue a ruling on the declaration of bankruptcy in which, among others, appoints a trustee $^{27}$ and a judge - commissioner (art. $51 \mathrm{sec} .1$ point 6 b.r.l.). ${ }^{28}$ The ruling declaring bankruptcy shall be effective and enforceable from the date of its issuance.

There are many legal results of declaring consumer bankruptcy. First of all it should be pointed that the declaration of the consumer bankruptcy shall not effect the bankrupt's legal capacity and his capacity to perform legal acts (art. 185 sec. 2 b.r.l.). ${ }^{29}$ The bankrupt shall indicate and release all of his assets to the trustee and shall provide all necessary explanations concerning his assets to the judge-commissioner and the trustee (art. 57 b.r.l.). ${ }^{30}$

On the day bankruptcy is declared the bankrupt's assets shall become the bankruptcy estate. The bankruptcy estate shall comprise assets belonging to the bankrupt on the day of announcement of bankruptcy as well as those acquired by the bankrupt in the course of bankruptcy proceedings (art. $61-62$ b.r.l.). ${ }^{31}$ The bankrupt shall lose the right of administration and the possibility to use and dispose of the assets included in the bankruptcy estate (art. $75 \mathrm{sec} .1$ b.r.l.). Legal acts of the bankrupt concerning the assets included in the bankruptcy estate, with regard to which the bankrupt has lost the right of administration shall be null and void (art. 77 sec. 1 b.r.l.). On the day of declaration of the bankruptcy

25 R. Adamus, Prawo naprawcze przedsiębiorcy, Warszawa 2009, p. 128.

26 In general bankruptcy proceedings bankruptcy by liquidation may convert into bankruptcy with the possibility to make an arrangement. Bankruptcy with the possibility to make an arrangement may convert into bankruptcy by liquidation (art. 16, 17 b.r.l.). R. Adamus, Zmiana trybu postępowania upadłościowego upadłej spółki handlowej, Prawo Spółek 2011, no 1, p. 23.

27 In Polish: ,syndyk”.

28 A. Jakubecki, in: Prawo..., p. 115, S. Gurgul, in: Prawo..., p. 157, S. Ociessa, in: Prawo..., p. 151.

29 F. Zedler, in: Prawo..., p. 438, S. Gurgul, in: Prawo..., p. 642, L. Zieliński, in: Prawo..., p. 378.

30 F. Zedler, in: Prawo..., p. 173, S. Gurgul, in: Prawo..., p. 281, S. Ociessa, in: Prawo..., p. 163.

31 F. Zedler, in: Prawo ..., p. 138, D. Chrapoński, Wyłączenia z masy upadłości, Warszawa 2010, p. 21, S. Gurgul, Prawo..., p. 190, P. Janda, Sposoby zaspokajania roszczeń w postępowaniu upadłościowym obejmującym likwidację majątku upadłego, Warszawa 2007, p. 44, S. Cieślak, Fundusze masy upadłości - postępowanie podziałowe. Komentarz, Warszawa 2004, p. 21. 
of one of the spouses a "separate property regime" (as defined in art. $53 \mathrm{sec} .1$ of the Act of 25 February 1964 - the Family and Guardianship Code) shall be created between the spouses. If the marital estate was held by the spouses as "joint, indivisible property", the joint marital estate shall be included in the bankruptcy estate and its division shall be inadmissible (art. $124 \mathrm{sec} .1$ b.r.l.). It also should be mentioned that the bankrupt's spouse may, in the bankruptcy proceedings, assert a claim arising from his share in the joint marital estate by submitting the claim to the judge - commissioner (art. $124 \mathrm{sec} .3$ b.r.l.). ${ }^{32}$ The legal position of the bankrupt's spouse is much worse in the consumer bankruptcy than in case of execution proceedings against the debtor. Of course both spouses may file the petition to declare bankruptcy. There are not any provisions concerning the consolidation of the bankruptcy cases conducted against the spouses. De lege ferenda art. 215 b.r.l. concerning the consolidation of the bankruptcy cases against the partners of a civil partnership and against partners liable without limitation with their all property for the obligations of the commercial partnership should apply accordingly in the case of the spouses in bankruptcy.

The judge-commissioner shall determine the manner and the time period during which the apartment located in the premises or in the building included in the bankruptcy estate, may be occupied by the bankrupt and his close associates who occupied the apartment at the time the consumer bankruptcy was declared (art. $75 \mathrm{sec} .2$ b.r.l.). ${ }^{33}$ The judge-commissioner may decide that the bankrupt cannot leave the territory of the Republic of Poland without court's permission (art. 57 sec. 3 b.r.l.).

As a general rule, monetary obligations of the bankrupt, the payment date of which has not yet become due, shall become due on the day of declaring consumer bankruptcy (art. $91 \mathrm{sec} .1$ b.r.l.). Non - monetary obligations shall - on the day of declaring bankruptcy - be converted into monetary obligations and on that day they shall become payable, even if the day of their performance has not yet become due (art. 91 sec. 2 b.r.l.). Interest accrued on claims due from the bankrupt for a period prior to the declaration of bankruptcy, may be satisfied from the bankrupt estate (art. $92 \mathrm{sec} .1$ b.r.l.). ${ }^{34}$

If on the date bankruptcy is declared the obligations arising under a reciprocal agreement (do ut des) have not been performed in part or in full the trustee may perform the obligation of the bankrupt and request that the other party render the reciprocal performance or the trustee may rescind the reciprocal agreement (art. $98 \mathrm{sec} .1$ b.r.l.). ${ }^{35}$ If the trustee performs the reciprocal agreement

32 A. Jakubecki, in: Prawo..., p. 271, S. Gurgul, in: Prawo..., p. 442, D. Chrapoński, in: Prawo..., p. 287.

33 F. Zedler, in: Prawo..., p. 168, S. Gurgul, in: Prawo..., p. 272, D.Chrapoński, in: Prawo..., p. 209

34 A. Jakubecki, in: Prawo..., p. 197, S. Gurgul, in: Prawo..., p. 332.

35 M. Pannert, Wpływ upadłości likwidacyjnej na wykonywanie zobowiązań z umów wzajemnych, Warszawa 2010, p.57, J. Kruczalak - Jankowska, Ogłoszenie upadłości. Skutki dotyczące zobowiązań w krajowym i transgranicznym postępowaniu upadłościowym, 
amounts resulting from the actions of the trustee are classified in the class one of the distribution scheme (art. $342 \mathrm{sec} .1$ point 1 b.r.l.). The trustee shall satisfy the claims of the class one as the appropriate amounts are successively contributed to the bankruptcy estate (art. $343 \mathrm{sec} .1$ b.r.l.). If the trustee rescinds the reciprocal agreement, the other party shall not be entitled to the return of the render performance, even if the performance remains in the bankruptcy estate. The party is entitled to pursue in the bankruptcy proceedings both the remuneration for the performed obligation and compensation for the damage suffered, submitting the claims to the judge-commissioner (art. 99 b.r.l.). The Bankruptcy and Reorganization Law provides special effects of declaring the bankruptcy for concrete types of legal relationship : mandate agreement, loan, use agreement, bank credit agreements, safe - keeping agreements etc. ${ }^{36}$

As the legal effect of declaring consumer bankruptcy court and administrative proceedings concerning the bankruptcy estate may be opened only by the trustee or against him (art. $144 \mathrm{sec} .1$ b.r.l.). Execution proceedings - court and administrative - against the bankrupt prior to the declaration of bankruptcy shall be suspended by force of law on the day of the declaration bankruptcy. Execution proceedings shall be discontinued by force of law after the ruling on the declaration of bankruptcy becomes legally valid (art. $146 \mathrm{sec} .1$ b.r.l.). ${ }^{37}$

The bankruptcy court shall immediately request information from the head of the relevant tax office for the bankrupt, whether the bankrupt within last five years prior to filing of the bankruptcy petition reported the conduct of any taxable activities and the court shall examine in Krajowy Rejestr Sadowy (the National Court Register) whether the bankrupt is a partner or a shareholder in any commercial partnership or company (art. $491^{2}$ sec. 4 b.r.l.).

\section{Submission and confirmation of claims}

A personal creditor of the bankrupt who wishes to participate in the bankruptcy proceedings shall, if the establishment of his claim is necessary, within the period stated in the ruling on a declaration of bankruptcy, submit his claim to the judge-commissioner (art. $236 \mathrm{sec} .1$ b.r.l.). Some of the claims shall be recorded on the list of claims ex officio (art. $236 \mathrm{sec}$. 2-3, art. 237, 238 b.r.l.). The list of claims shall be drafted by the trustee (art. 244 b.r.l.). Creditors have right to file objections against the drafted list of claims (art. 255 b.r.l.). Finally the list of claims shall be confirmed by the judge - commissioner (art. 260 b.r.l.). ${ }^{38}$ If a claim is filed after the deadline for filing the claim has already elapsed such claim should be recorded on a supplementary list of claims (art. 261 sec. 1 b.r.l.). In

Warszawa 2010, p. 115.

36 M. Pannert, Wpływ upadłości likwidacyjnej..., p. 193, J. Kruczalak - Jankowska, Ogłoszenie upadłości..., p. 145.

37 A. Jakubecki, in: Prawo..., p. 334, S. Gurgul, in: Prawo..., p. 521.

38 A. Jakubecki, in: Prawo..., p. 515, S. Gurgul, in: Prawo..., p. 760. 
practice the establishment of the list of claims (including objections to the list of claims, approval, rectification and supplementation of the list of claims) takes a very long period time. The extract from the list of claims approved by the judge commissioner, containing the specification of the claim and the amount received on his account by the creditor, shall represent an enforcement title against the bankrupt. In fact the extract from the list of claims is equal to the court sentence.

\section{Liquidation of the bankruptcy estate}

There are two main stages of the consumer bankruptcy proceedings: the liquidation of the bankruptcy estate and the repayment plan with its further consequence - discharging unsatisfied obligations of the bankrupt. The sequence of the two stages of the proceedings clearly shows the legal nature of the Polish consumer bankruptcy in the present shape. The characteristic feature of consumer bankruptcy is rather relatively strong protection of the creditors. Article 2 b.r.l. stipulates that the proceedings govern by the Bankruptcy and Reorganization Law should be conducted in a manner which provides for the maximum satisfaction of the creditor's claims. ${ }^{39}$

If a bankrupt goes into hiding or conceals its assets the judge - commissioner may impose coercive measures to execute non - pecuniary performances on the bankrupt, as specified in the Code of Civil Proceedings (art. 58 sec. 1 b.r.l.). Under art. $491^{4}$ b.r.l. if the bankrupt does not disclose and realize all of his assets or necessary documents to the trustee or in any other manner fails to perform his duties, the court shall discontinue the proceedings.

As a rule the process of the liquidation of the assets of the bankruptcy estate is the duty of the trustee. Article 308 b.r.l. clearly provides that after preparing inventory the trustee shall carry out the liquidation of the bankruptcy estate. There is one significant exemption of the above mentioned rule in the consumer bankruptcy. The judge - commissioner may allow for the liquidation of the bankruptcy estate by the bankrupt under the supervision of the trustee (art. $491^{2}$ sec. 5 b.r.l.). ${ }^{40}$ The liquidation conducted by the bankrupt himself may decrease the costs of the proceedings.

If an apartment or a single - family house in which the bankrupt reside is included in the bankruptcy estate an amount equivalent to an average apartment lease rent for a period of twelve months shall be assigned to the bankrupt from the proceeds of a sale of thereof, according to the ruling of judge - commissioner (art. $491^{6}$ b.r.l.). ${ }^{41}$

39 R. Adamus, Przedsiębiorstwo upadłego w upadłości likwidacyjnej, Warszawa 2011, p. 49.

40 A.J. Witosz, Likwidacja własna masy upadłości przez konsumenta, Monitor Prawniczy 2009, no 19.

41 F. Zedler, in: Prawo..., p. 929, S. Gurgul, in: Prawo..., p. 1269, R. Adamus, A.J. Witosz, A. Witosz, in: Prawo..., p. 838. 
After bankruptcy by liquidation of the bankrupt's assets has been declared, the trustee shall immediately proceed to prepare the inventory and the appraisal of the property of the bankruptcy estate and the liquidation plan. The liquidation plan shall include the proposed method of selling the bankrupt's assets, in particular the day of sale, estimate of expenses, etc. (art. 306 b.r.l.). The liquidation of the bankruptcy estate shall be performed by selling all immovable and movable property, be enforcing claims against the debtors of the bankrupt, and by exercising other proprietary rights included in the bankruptcy estate or by alienation thereof (art. $311 \mathrm{sec}$. b.r.l.). The sale of some kinds of assets (real property, perpetual usufruct right, co-operative ownership right to premises) shall be effected by the way of tender or auction (art. 320 b.r.l.). ${ }^{42}$ The bankrupt's claims shall be liquidated by way of their execution. If the execution of the bankrupt's claims is impaired or the claim is not yet due, such claims should be liquidated by their alienation (art. 331 b.r.l.). The bankrupt's proprietary rights shall be liquidated by the way of exercising or alienation (art. 332 b.r.l.).

The bankruptcy estate funds shall be distributed to the creditors once or several times as the bankruptcy estate is successively liquidated, following the approval of the list of claims (art. $337 \mathrm{sec} .1$ b.r.l.). The trustee shall prepare and submit to the judge - commissioner a distribution plan of the bankruptcy funds (art. 347 sec. 1 b.r.l.). The creditors are entitled to submit objections to the distribution plan (art. 350 b.r.l.). ${ }^{43}$

The Bankruptcy and Reorganization Law provides particular rules on distribution scheme related to claims secured be a mortgage, pledge, registered pledge, tax lien and maritime mortgage (art. 345 b.r.l. and following) ${ }^{44}$ There are also general rules on distribution scheme to unsecured claims (art. 342 b.r.l. and following). ${ }^{45}$ There are five classes of amounts subject to satisfaction from the bankruptcy estate funds. In the class one there are inter alia the costs of bankruptcy proceedings, alimony payments, amounts resulting from the actions of the trustee, In the class two there are amounts which very seldom occur in consumer bankruptcy. In the class three there are mainly taxes or other public levies. In the class four there are other amounts if they are not subject to satisfaction within class five. And in the class five there are interest not included in the classes of higher priority, to be satisfied in the order in which the principal amount is to be satisfied.

\section{Repayment plan and discharging obligation}

The repayment plan is a new institution in the Polish Bankruptcy and Reorganization Law. After the final distribution plan has been prepared, however not

42 A. Jakubecki, in: Prawo..., p. 636, S. Gurgul, in: Prawo..., p. 916, L. Guza, in: Prawo..., p. 566.

43 A. Jakubecki, in: Prawo..., p. 705, S. Gurgul, in: Prawo..., p. 1013, L. Guza, in: Prawo..., p. 608.

44 R. Adamus, Upadłość a hipoteka na mieniu upadłego, Warszawa 2009.

45 A. Jakubecki, in: Prawo..., p. 713, S. Gurgul, in: Prawo..., p. 1013, L. Guza, in: Prawo..., p. 613. 
earlier than after the bankrupt vacates the single-family house or apartment, the bankruptcy court shall issue a ruling on the establishment of the bankrupt's creditors repayment plan. The repayment plan should specify the extent and timeframe in which the bankrupt shall pay all the claims not satisfied under the distribution plan and specifying the part of the bankrupt's obligations shall be discharged after the bankrupt performs the creditors repayment plan. The above mentioned timeframe should not exceed a period of 5 years. ${ }^{46}$ The creditors repayment plan shall include all of the obligations of the bankrupt which arose to the day of the plan's establishment (art. $491^{7} \mathrm{sec} .1$ b.r.l.). ${ }^{47}$ In other words thr repayment plan shall include amounts resulting from the actions of the trustee, as well. In matters concerning the bankruptcy estate the trustee acts on behalf of the bankrupt but in his own name (art. $160 \mathrm{sec} .1$ b.r.l.). If all obligations of the creditors are satisfied in the effect of the distribution of bankruptcy estate funds, which comprise the proceeds of liquidating the bankruptcy estate, the repayment plan is not necessary. On the day the ruling on establishment of the creditors repayment plan becomes final and valid the appointment of the trustee shall expire by virtue of law (art. $491^{8}$ b.r.l.). ${ }^{48}$

During the performance of the creditors repayment plan the bankrupt may not perform legal transactions exceeding the scope of ordinary management (art. $491^{9}$ sec. 1 b.r.l.). In the same time the bankrupt may incur obligations necessary to support himself and the persons with regard to whom the bankrupt is under a statutory obligation to support, except for the purchases in consideration for payment in installments or deferred payment (art. $491^{9}$ sec. 2 b.r.l.). ${ }^{49}$

If the bankrupt may not perform the obligations prescribed in the creditors repayment plan, due to temporary impediments, the bankruptcy court, upon the motion of the bankrupt and after having heard the creditors, has power to amend the repayment plan. The court may extend the deadline to repay the creditors up to total period of 2 years or change the amount of individual payments (art. $491^{10}$ sec. 1 b.r.l.). On the hand if the bankrupt's financial condition has remarkably improved during the period of performance of the creditor repayment plan (but due to the reasons other than the increase of remuneration for work or income derived from gainful activity performed by the bankrupt) any of the creditors is entitled to demand that the creditors repayment plan be changed and the amounts due to the creditors be increased. The bankruptcy court shall decide in the matter after conducting a trial (art. $491^{10}$ sec. 1 b.r.l.). ${ }^{50}$

46 In practice courts appoint shorter periods of time for repayment plans.

47 F. Zedler, in: Prawo..., p. 931, S. Gurgul, in: Prawo..., p. 1272, R. Adamus, A.J. Witosz, A. Witosz, in: Prawo..., p. 842.

48 F. Zedler, in: Prawo..., p. 935, S. Gurgul, in: Prawo..., p. 1277, R. Adamus, A.J. Witosz, A. Witosz, in: Prawo..., p. 848.

49 F. Zedler, in: Prawo..., p. 936, S. Gurgul, in: Prawo..., p. 1278, R. Adamus, A.J. Witosz, A. Witosz, in: Prawo..., p. 850.

50 F. Zedler, in: Prawo..., p. 938, S. Gurgul, in: Prawo..., p. 1284, R. Adamus, A.J. Witosz, A. 
The bankruptcy court may revoke the creditors payment plan, upon the motion of a creditor, after having conducted a trial, if the bankrupt does not perform his obligations stipulated in the repayment plan (art. $491^{11} \mathrm{sec} .1$ b.r.l.). The Act prescribes a couple of other reasons which result the revocation of the repayment plan (art. $491^{11} \mathrm{sec} .2$ b.r.l.). ${ }^{51}$

After the bankrupt has performed all the obligations under the repayment plan the bankruptcy court shall issue a ruling on the discharge of the unsatisfied obligations of the bankrupt included in the repayment plan. The court shall indicate the creditor, the title and the amount of the obligation to be charged. The discharge of the obligation shall not concern those obligations of the bankrupt which include periodic payments to which the legal title has not yet expired and obligation which arose after the declaration of bankruptcy (art. $491^{12} \mathrm{sec}$. 1, 2, 3 b.r.l.). ${ }^{52}$ The court ruling in the matter of discharging obligations gives "a fresh start" for the debtor. Discharging obligations is an aspect of the consumer protection.

\section{Closure of the consumer bankruptcy}

The last item to be shortly presented is the closure of the consumer bankruptcy. The problem is not very complex. The bankruptcy court passes a ruling on the closure of the bankruptcy proceedings together with the ruling on discharging obligations (art. $491^{12}$ sec. 1 b.r.l.). ${ }^{53}$ The bankruptcy court shall discontinue the proceedings if the bankrupt does not disclose and release all of his assets or necessary documents to the trustee or in any other way fails to perform his duties (art. $491^{4}$ b.r.l.). ${ }^{54}$ The bankruptcy court shall also discontinue the proceedings if there are no sufficient assets to satisfy the costs of the proceedings (art. 361 point 1 b.r.l.)..$^{55}$

\section{Conclusions}

The practice in Poland shows that legal knowledge of the debtors who are natural persons and who are not entrepreneurs is very small. It happens that debtors are unaware that bankruptcy proceedings involves selling out their apartments and the estate. The present legal construction of the bankruptcy proceedings is not available for many debtors. There are a couple of reasons of such a situation.

Witosz, in: Prawo..., p. 853.

51 F. Zedler, in: Prawo..., p. 940, S. Gurgul, in: Prawo..., p. 1285, R. Adamus, A.J. Witosz, A. Witosz, in: Prawo..., p. 857.

52 F. Zedler, in: Prawo..., p. 942, S. Gurgul, in: Prawo..., p. 1287, R. Adamus, A.J. Witosz, A. Witosz, in: Prawo..., p. 860.

53 F. Zedler, in: Prawo..., p. 942, S. Gurgul, in: Prawo..., p. 1287, R. Adamus, A.J. Witosz, A. Witosz, in: Prawo..., p. 860.

54 F. Zedler, in: Prawo..., p. 927, S. Gurgul, in: Prawo..., p. 1266, R. Adamus, A.J. Witosz, A. Witosz, in: Prawo..., p. 835.

55 F. Zedler, in: Prawo..., p. 753, S. Gurgul, in: Prawo..., p. 1065, L. Guza, in: Prawo..., p. 636. 
ICLR, 2011, Vol. 11, No. 2.

The legal basis for declaration of consumer bankruptcy are very complex. The bankruptcy courts very often dismiss the petition for a declaration of consumer bankruptcy because the consumer's estate is not sufficient to satisfy the costs of the proceedings. The perspective of liquidation of the bankrupt's estate does not encourage the debtors for submitting the petitions for declaration of bankruptcy, etc. The present regulation of the consumer bankruptcy is waiting for the very serious legal changes in order to be useful in practice. 